\title{
ANALISIS TATANIAGA KOPRA DI DESA BALOBONE KECAMATAN MAWASANGKA KABUPATEN BUTON TENGAH
}

\author{
Wa Ode Al Zarliani \\ Program Studi Agribisnis, Fakultas Pertanian \\ Universitas Muhammadiyah Buton \\ Jl. Betoambari No. 36 Baubau \\ e-mail: waodealzalian@yahoo.com
}

\begin{abstract}
This research was conducted in Balobone Village, Mawasangka Sub-district, Central Buton Regency. Coconut farmers in Balobone village have problems, in addition to the low quality of copra as well as price fluctuations in a short time often occur in copra marketing so that it affects the marketing efficiency that is formed. For this reason, a comprehensive assessment of the most efficient copra marketing system needs to be carried out, so that it can provide a proportional income contribution for farmers. The objectives of this study are: (1) Knowing copra marketing channels in Balobone Village; (2) Knowing the number of costs, margins and profits received by each marketing institution involved in copra marketing in Balobone Village; (3) Analyzing copra market performance in Balobone Village through analysis of marketing margins and producer share. The sampling procedure is carried out in an institutional approach with a snowball sampling method with the amount adjusted to field conditions and research analysis needs. Marketing channel analysis is done descriptively qualitatively to see the pattern of marketing channels formed during the copra drainage process from producer farmers to exporter traders. The conclusions of the research are (1) Farmers in marketing copra produced through 2 patterns of marketing channels, namely: $a$. The pattern I Marketing Channels: Inter-island Traders Surabaya Big Surabaya Traders. (2) The result of Analysis of Marketing Margin 1 received by traders shows that the marketing margin of the village collecting trader is IDR 600/Kg, costs IDR 350/Kg, Profits IDR 250/Kg, while the marketing margin of the big traders in Baubau Town is IDR 3,700/kg, with the cost IDR 1,354.5/kg, the profit received is IDR 2,543.5/ kg. Pattern 2 marketing margin received by inter-island traders is IDR 4,300, with a total cost of IDR $1,354.5 / \mathrm{Kg}$, with a profit of IDR $2,945.5 / \mathrm{Kg}$; (3) The percentage of the price received by farmers from each of the marketing channels I patterns is 53\% and the marketing channel pattern 2 is 53. Thus, the copra marketing system of the 2 marketing channel patterns formed in Balobone Village is efficient. Farmers, Village Traders, Large Village Traders, Large Traders I (Exporters); (b) Marketing Channel Pattern II: Farmers.
\end{abstract}

Keywords: Copra, marketing margins, marketing channels

\begin{abstract}
Abstrak
Penelitian ini dilakukan di Desa Balobone, Kecamatan Mawasangka, Kabupaten Buton Tengah. Petani kelapa di Desa Balobone memiliki beberapa masalah, selain kualitas kopra yang rendah serta fluktuasi harga dalam waktu singkat sering terjadi pada pemasaran kopra sehingga mempengaruhi efisiensi pemasaran yang terbentuk. Untuk itu, penilaian
\end{abstract}




\section{Media Agribisnis}

Vol. 3, Issue 2, November 2019

P-ISSN: 2527-8479 E-ISSN: 2686-2174

komprehensif terhadap sistem pemasaran kopra yang efisien perlu dilakukan, sehingga dapat memberikan kontribusi pendapatan yang proporsional bagi petani. Tujuan dari penelitian ini adalah: (1) Mengetahui saluran pemasaran kopra di Desa Balobone; (2) Mengetahui jumlah biaya, margin dan keuntungan yang diterima oleh masing-masing lembaga pemasaran yang terlibat dalam pemasaran kopra di Desa Balobone; (3) Menganalisa kinerja pasar kopra di Desa Balobone melalui analisis margin pemasaran dan pangsa produsen. Prosedur pengambilan sampel dilakukan dalam pendekatan kelembagaan dengan metode pengambilan sampel snowball dengan jumlah yang disesuaikan dengan kondisi lapangan dan kebutuhan analisis penelitian. Analisis saluran pemasaran dilakukan secara deskriptif kualitatif untuk melihat pola saluran pemasaran yang terbentuk selama proses drainase kopra dari petani produsen ke pedagang eksportir. Kesimpulan dari penelitian ini adalah (1) Petani dalam pemasaran kopra diproduksi melalui 2 pola saluran pemasaran, yaitu: a. Pola I Saluran Pemasaran: Pedagang Antar Pulau Surabaya - Pedagang Besar Surabaya. (2) Hasil Analisis Margin Pemasaran 1 yang diterima oleh pedagang menunjukkan bahwa margin pemasaran pedagang pengumpul desa adalah $\mathrm{Rp} 600 / \mathrm{Kg}$, biaya $\mathrm{Rp} 350 / \mathrm{Kg}$, keuntungan $\mathrm{Rp} 250 / \mathrm{Kg}$, sedangkan margin pemasaran pedagang besar di Kota Baubau adalah Rp 3.700/kg, dengan biaya $\mathrm{Rp} 1.354,5 / \mathrm{kg}$, keuntungan yang diterima adalah Rp 2.543.5/kg. Margin pemasaran pola 2 yang diterima oleh pedagang antar pulau adalah $\mathrm{Rp} 4.300$, dengan total biaya $\mathrm{Rp}$ $1.354,5 / \mathrm{Kg}$, dengan laba Rp $2.945,5 / \mathrm{Kg}$; (3) Persentase harga yang diterima petani dari masing-masing pola saluran pemasaran I adalah 53\% dan pola saluran pemasaran 2 adalah 53. Dengan demikian, sistem pemasaran kopra dari 2 pola saluran pemasaran yang dibentuk di Desa Balobone tersebut efisien. Petani, Pedagang Desa, Pedagang Desa Besar, Pedagang Besar I (Eksportir); b. Saluran Pemasaran Pola II: Petani.

Kata kunci: kopra, margin pemasaran, saluran pemasaran

\section{PENDAHULUAN}

Sektor pertanian memiliki peran penting dalam perekonomian Indonesia yang memberikan kontribusi sumber devisa negara, sumber utama minyak dalam negeri, sumber bahan baku industry, sumber pendapatan masyarakat petani dan penyedia lapngan kerja. Salah satu tujuan pembangunan pertanian adalah meningkatkan hasil produksi yang nantinya akan berdampak pada peningkatan kesejahteraan masyarakat petani (Tarigans 2003).

Pengembangan dalam sektor agribisnis tanaman kelapa sangat penting sebagai pohon kehidupan dengan berbagai aspek fungsi. Karena bagian tanaman dapat dimanfaatkan untuk kebutuhan manusia. Jika ditelaah penggunaan pengelolaan kelapa dalam proses produksi sangat berhubungan dengan proses pengelolaan kopra untuk kepentingan industri minyak kelapa, industri pembuatan sabun dan bahan sumber nabati lainnya.

Tanaman kelapa merupakan salah satu tanaman yang telah dibudidayakan oleh masyarakat Sulawesi Tenggara baik menggunakan lahan pemukiman dengan jumlah yang terbatas maupun yang dilakukan pada lahan yang luas untuk tujuan kemersial. Berdasarkan data Statistik tahun 2017 menunjukkan bahwa luas areal tanaman kelapa dalam untuk wilayah Sulawesi Tenggara tahun 2015 mencapai luas tanam 54.180 Hektar dengan pencapaian produksi 39.271 Ton. Sedangkan pada tahun 2016 luas areal tanaman 57.100 Hektar dengan pencapaian produksi sebesar 41.850 Ton. Keadaan ini menunjukkan bahwa terjadi peningkatan baik luas tanam yang menghasilkan maupun pencapaian produksi yang dihasilkan. Dengan peningkatan produksi kelapa dalam yang dihasilkan tersebut akan 


\section{Media Agribisnis}

Vol. 3, Issue 2, November 2019

\section{P-ISSN: 2527-8479 E-ISSN: 2686-2174}

mempengaruhipeningkatan pendapatan petani. Akan tetapi peningkatan pendapatan tersebut dapat dicapai jika faktor- faktor yang lain mendukung terutama pada pemasaran yang terjadi.

Salah satu kabupaten yang ada dalam wilayah Sulawesi Tenggara yang melakukan kegiatan usahatani kelapa dalam adalah Kabupaten Buton yang cukup potensial untuk pengembangan usahatani kelapa dalam. Untuk lebih jelas mengenai perkembangan luas areal tanaman dan produksi yang dihasilkan dalam 3 tahun dapat dilihat pada Tabel 1.

Tabel 1. Perkembanagan Luas dan Produksi Kelapa Dalam Kabupaten Buton Tahun 2014 2016

\begin{tabular}{ccc}
\hline Tahun & Luas Tanam $(\mathrm{Ha})$ & Produksi (Ton) \\
\hline 2014 & 3.051 & 1.707 \\
\hline 2015 & 3.509 & 1.701 \\
\hline 2016 & 2.000 & 804
\end{tabular}

Sumber: Sulawesi Tenggara Dalam Angka, 2017

Berdasarkan pada Tabel 1 menunjukkan bahwa pada tahun 2014 luas tanam kelapa sebesar 3.051 Hektar dengan jumlah produksi yang dihasilkan sebesar 1.707 Ton. Sedangkan pada tahun 2015 luas tanaman sebesar 3.509 Hektar dengan pencapaian produksi sebesar 1.707 Ton dan pada tahun 2016 sebesar 2.000 Hektardengan jumlah produksi yang dihasilkan sebesar 804 Ton. Keadaaan ini menggambarkan bahwa dalam 3 tahun terakhir ini dari tahun 2014 telah terjadi penurunan pada luas tanam yang menghasilkan sebesar 1.051 Hektar dan penurunan produksi sebesar 903 Ton jika dibandingkan dengan tahun 2016.Namun kondisi perkembangan produksi kelapa dalam yang mengalami fluktuasi tersebut tidak terjadi secara merata untuk wilayah kecamatan yang ada di wilayah Kabupaten Buton. Salah satunya adalah Kecamatan Mawasangka yang dalam 3 tahun terakhir tidak mengalami fluktuasi baik untuk luas maupun produksi yang dihasilkan. Mengenai perkembangan luas dan produksi kelapa dalam dapat dilihat pada Tabel 2

Tabel 2. Perkembangan Luas, Produksi Kelapa Dalam Kecamatan Mawasangka Tahun 2014 2016

\begin{tabular}{ccc}
\hline Tahun & Luas Tanam $(\mathrm{Ha})$ & Produksi (Ton) \\
\hline 2014 & 934,5 & 595 \\
\hline 2015 & 934,5 & 595 \\
\hline 2016 & 934,5 & 595
\end{tabular}

Sumber: Kecamatan Mawasangka Dalam Angka, 2017

Informasi yang ada pada Tabel 2 menunjukkan bahwa luas kelapa dalam pada tahun 2014 sebesar 934,5 Hektar dengan pencapaian produksi 595 Ton. Demikian halnya dengan luas dan produksi yang dihasilkan tahun 2015 dan 2016. Kondisi ini disebabkan umur tanaman kelapa lebih dari 20 tahun, kurangnya pengetahuan dari petani untuk melakukan pemeliharaan sehinggga mengakibatkan tidak terjadi peningkatan produksi yang dihasilkan. Dari hasil tersebut produksi kopra yang dihasilkan Kecamatan Mawasangka tahun 2016 


\section{Media Agribisnis}

Vol. 3, Issue 2, November 2019

P-ISSN: 2527-8479 E-ISSN: 2686-2174

sebesar 250 Ton. Pencapaian produksi yang dihasilkan Kecamatan Mawasangka tersebut merupakan bagian dari kontribusi yang diberikan Desa Balobone.

Desa Balobone merupakan salah satu desa yang ada di Kecamatan Mawasangka yang cukup potensial dalam pengembangan usahatani kelapa dalam. Berdasarkan hasil observasi awal menunjukkan bahwa sebagian besar petani yang ada berusahatani kelapa dan melakukan kegiatan pengolahan kelapa dalam menjadi kopra, melakukan kegiatan pengolahan secara individu. Produk kopra yang dihasilkan tersebut selanjutnya dipasarkan di Kota Baubau melalui pedagang pengumpul desa dan pedagang pengumpul memasarkan kopra tersebut kepada pedagang ekportir untuk selanjutnya dipasarkan di Kota Makasar dan Surabaya untuk dilakukan proses pengolahan dalam industry. Kondisi tersebut tentu akan mempengaruhi efisiensi pemasaran yang terbentuk. Dalam proses pemasaran kopra tersebut terdapat permasalahan yang ditemukan dilapangan keberadaan pedagang pengumpul Desa Balobone dalam jumlah yang relatif sedikit dibandingkan dengan jumlah petani yang melakukan kegiatan pengolahan kopra, kurangnya akses informasi pasar terutama harga kopra, adanya hubungan yang kuat antara petani dengan pedagang pengumpul sehingga petani dalam mengatasi permasalahan keuangan melakukan peminjaman kepada pedagang pengumpul dengan kompensasi petani akan melakukan penjualan kepada pedagang tersebut mengakibatkan petani tdak memiliki kekuatan untuk melakukan penawaran pada saat melakukan penjualan, modal yang dimiliki dalam jumlah yang kecil, produksi kopra yang dihasilkan dalam jumlah yang relatif sedikit sehingga petani langsung melakukan penjualan tanpa ada pertimbangan untuk menyimpan produk kopra sampai menunggu harga layak yang menguntungkan.

Berdasarkan kondisi proses pemasaran tersebut akan mempengaruhi harga jual kopra yang berlaku ditingkat petani sehingga akan mempengaruhi pendapatan yang diterima oleh petani sebagai penghasil kopra. Sebagai salah satu sentra produksi kelapa, pendapatan petani kelapa di Desa Balobone sangat ditentukan oleh kontribusi hasil usahatani komoditi kelapa tersebut. Pendapatan petani disamping dipengaruhi oleh tingkat produktivitas per satuan luas juga sangat dipengaruhi oleh mampu tidaknya petani memasarkan hasil usahataninya kepada konsumen dengan harga yang memadai. Penyebab rendahnya pendapatan petani adalah kesenjangan harga di tingkat petani dibandingkan dengan harga pada tingkat konsumen akhir. Hal ini terjadi karena besarnya keuntungan yang diambil oleh para pedagang perantara dan biaya yang dikeluarkan dalam memasarkan kopra sampai tingkat konsumen akhir.

Kondisi permasalahan pemasaran tersebut, petani pengolah kopra dalam melakukan kegiatan pengolahan masih bersifat tradisional, yang bekerja tanpa memperhatikan syaratsyarat atau tahapan yang harus dilakukan, yang menyebabkan rendahnya kualitas kopra yang dihasilkan. Dengan rendahnya kualitas yang dihasilkkan berdampak langsung pada harga yang diterima oleh petani juga rendah. Dengan kondisi kualitas yang rendah tentunya juga berdampak pada fungsi-fungsi pemasaran yang dilakukan oleh setiap lembaga pemasaran. Dalam hal ini terkait dengan proses penyimpanan yang tidak dapat dilakukan dalam waktu lama sampai menunggu harga kopra berada pada harga yang mengunntungkan dengan pertimbangan bahwa kopra yang disimpan dalam waktu yang cukup lama akan menyebabkan kualitas kopra semakin rendah dan harganya semakin rendah. Disamping kualitas yang rendah juga faktor harga yang mengalami fluktuasi dan dalam waktu yang singkat sering terjadi dalam pemasaran kopra. Terjadinya fluktuasi harga tersebut akan mempengaruhi efisiensi pemasaran yang terbentuk. Untuk itu perlu pengkajian secara komprehensif sistem pemasaran kopra yang paling efisien dilakukan, dapat memberikan konstribusi pendapatan yang proporsional bagi petani. 
Berdasarkan uraian pada latar belakang diatas, maka dapat dirumuskan permasalahan yaitu:

1. Bagaimana saluran pemasaran kopra di Desa Balobone Kecamatan Mawasangka Kabupaten Buton Tengah

2. Berapa besar biaya, margin dan keuntungan yang diterima oleh tiap lembaga pemasaran yang terlibat dalam pemasaran kopra di Desa Balobone Kecamatan Mawasangka Kabupaten Buton Tengah

3. Bagaimana kinerja pasar kopra di Desa Balobone Kecamatan Mawasangka Kabupaten Buton Tengah

Adapun tujuan yang ingin dicapai dalam penelitian adalah untuk:

1. Mengetahui saluran pemasaran kopra di Desa Balobone Kecamatan Mawasangka Kabupaten Buton Tengah

2. Mengetahui besarnya biaya, margin dan keuntungan yang diterima oleh tiap lembaga pemasaran yang terlibat dalam pemasaran kopra di Desa Balobone Kecamatan Mawasangka Kabupaten Buton Tengah

3. Menganalisis kinerja pasar kopra di Desa Balobone Kecamatan Mawasangka Kabupaten Buton melalui analisis margin pemasaran dan pangsa produsen

Hasil penelitian ini diharapkan dapat berguna sebagai:

1. Bahan informasi bagi para petani dalam mementukan lembaga pemasaran yang dijadikan sebagai mitra dalam memasarkan kopra yang dihasilkan sehingga petani memperoleg bagian harga yang adil dan menguntungkan

2. Bahan informasi bagi para peneliti lain khususnya yang berkaitan dengan pemasaran kelapa dan kopra

3. Bahan informasi dan masukan bagi pemerintah khususnya instansi terkait, dalam hal ini Dinas Pertanian Kabupaten Buton sebagai pelaku pengambil kebijakan di bidang pertanian.

4. Sebagai pengimplementasian ilmu pengetahuan yang telah diperoleh selama dibangku kuliah

\section{METODE PENELITIAN}

Populasi dalam penelitian ini adalah keseluruhan petani di Desa Balobone yang mengusahakan pengolahan kelapa dalam yang berjumlah 140 orang (KK). Penentuan Sampel dilakukan dengan cara acak sederhana (simple sandom sampling) dengan mengambil $20 \%$ dari jumlah populasi sehingga diperoleh jumlah sampel sebanyak 30 orang. Besarnya sampel ditentukan berdasarkan kriteria bahwa jumlah sampel yang diambil paling sedikit sebanyak 10\% dari besarnya populasi seperti yang dikemukakan oleh Singarimbun dan Effendi (1989). Prosedur penentuan lembaga pemasaran sampel dilakukan dengan caranon probability sampling mengingat besarnya populasinya tidak diketahui. Prosedur ini merupakan prosedur pengambilan sampel dimana peluang dari anggota populasi untuk muncul sebagai sampel tidak diketahui (Nazir, 1999). Prosedur pengambilan sampelnya dilakukan secara pendekatan kelembagaan dengan metode snowball sampling dengan jumlah yang disesuaikan dengan kondisi lapangan dan kebutuhan analisis penelitian. Penentuan lembaga ini dibatasi sampai pada tingkat pedagang pengumpul desa dan pedagang besar.

Variabel yang diamati dalam penelitian ini adalah: 


\section{Media Agribisnis}

Vol. 3, Issue 2, November 2019

P-ISSN: 2527-8479 E-ISSN: 2686-2174

1. Identitas responden: umur, pendidikan formal, pengalaman berusahatani, jumlah tanggungan keluarga, luas lahan garapan.

2. Identitas pedagang responen meliputi: umur, tingkat pendidikan, penagalaman berusahatani, jumlah tanggungan kelaurga

3. Jumlah Produksi kopra ( $\mathrm{Kg} / \mathrm{tahun})$

4. Harga jual kopra tingkat petani dan pedagang $(\mathrm{Rp} / \mathrm{Kg})$.

5. Biaya pemasaran yang dikeluarkan oleh lembaga pemasaran $(\mathrm{Rp} / \mathrm{Kg})$

6. Volume pembelian, volume penjualan lembaga pemasaran

7. Margin pemasaran, biaya dan keuntungan lembaga pemasaran

Data yang diperoleh ditabulasi, kemudian dianalisis secara deskriptif kualitatif dan kuantitatif. Analisis kualitatif dilakukan untuk mengetahui pola saluran pemasaran yang terbentuk selama proses pemasaran kopra sampai ketangan pedagang eksportir, mengetahui perilaku pasar kopra yang dilakukan oleh lembaga pemasaran dalam menghadapi persaingan pasar yang meliputi proses penentuan harga, sistem pembayaran dan kerjasama lembaga pemasaran. Analisis kuantitatif dilakukan untuk mengetahui tingkat efisiensi dengan indicator margin pemasaran, biaya dan keuntungan serta analisis farmer share untuk mengetahui saluran pemasaran atau peredaran kopra.

Analisis saluran pemasaran dilakukan secara deskriptif kualitatif untuk melihat pola saluran pemasaran yang terbentuk selama proses pengaliran kopra mulai dari petani produsen sampai ke pedagang eksportir. Dalam proses aliran pendistribusian kopra akan dapat dilihat panjang pendeknya rantai pemasaran dan akan dapat diketahui jumlah pedagang yang terlibat dan jumlah pola saluran pemasaran kopra yang terbentuk hingga sampai ke tangan pedagang eksportir.

Untuk mengetahui marjin pemasaran, biaya pemasaran, keuntungan pemasaran dan Farmer share (Producer Share) digunakan rumus (Angipora, 2005) dengan formulasi sebagai berikut:

Marjin pemasaran:

$\mathrm{Mm}: \mathrm{Pe}-\mathrm{Pf}$

Keterangan:

Mm : Marjin pemasaran di tingkat lembaga pemasaran

Pe : Harga jual produk di tingkat lembaga pemasaran

Pf : Harga beli produk di tingkat produsen

\section{Biaya dan keuntungan pemasaran:}

Karena dalam marjin pemasaran terdapat 2 komponen yaitu komponen biaya dan komponen keuntungan, maka:

$\mathrm{Mm}=\mathrm{n}+\mathrm{TC}$

$\mathrm{TC}=\mathrm{Mm}-\mathrm{n}$

Keterangan:

TC : Total biaya ditingkat lembaga pemasaran

it : Keuntungan di tingkat 
lembaga pemasaran

Mm : Marjin li produk di tingkat propemasaran di tingkat lembaga pemasaran

it $=\mathrm{Mm}-\mathrm{TC}$

Keterangan:

it : Keuntungan di tingkat lembaga pemasaran

Mm : Marjin li produk di tingkat propemasaran di tingkat lembaga pemasaran

TC : Total biaya ditingkat lembaga pemasaran

Bagian harga yang diterima produsen Farmer's share (Producer share)

$F S=\frac{(\mathrm{M})}{1 \times 100 \%}$

$\mathrm{He}$

Keterangan:

FS : Bagian harga diterima produsen Farmer's share (Producer's share)

$\mathrm{M}$ : Marjin pemasaran $(\mathrm{Rp} / \mathrm{Kg}$

He : Harga ditingkat lembaga pemasaran $(\mathrm{Rp} / \mathrm{Kg})$

\section{HASIL DAN PEMBAHASAN}

\section{Identitas Petani Responden}

a. Umur

Umur dapat mempengaruhi kemampuan fisik seseorang, baik dalam berpikir maupun dalam bekerja. Umur muda mempunyai kemampuan yang lebih tinggi bila dibandingkan dengan umur yang tua. Berdasarkan pendapat Soeharjo dan Dahlan P(1984) bahwa usia produktif berkisar antara $15-54$ tahun.Umur responden dalam penelitian ini bila ditinjau dari umur produktif dan kurang produktif maka yang mempunyai umur produktif (35 - 54) adalah 18 orang atau $60 \%$ dan umur yang kurang produktif (55-70) adalah 7 orang atau $40 \%$.

Kondisi ini menunjukan bahwa petani yang ada di desa Balobone diharapkan mampu menghasilkan kopra yang maksimal sebab dengan umur yang masih produktif petani akan lebih mempunyai tenaga yang lebih kuat atau memiliki kemampuan fisik yang lebih kuat dan pada umumnya memiliki pola pikir yang lebih baik, sehingga lebih mudah menerima ide-ide baru dan tanggap terhadap kemajuan teknologi dan semua akan berdampak positif pada kegiatan usahatani yang dilakukannya Untuk lebih jelasnya dapat dilihat pada Tabel 2 


\section{Media Agribisnis}

Vol. 3, Issue 2, November 2019

P-ISSN: 2527-8479 E-ISSN: 2686-2174

Tabel 2. Pengelompokan Responden Menurut Umur (Produktif/NonProduktif) di Desa Balobone Kecamatan MawasangkaTahun 2018

\begin{tabular}{cccc}
\hline No & $\begin{array}{c}\text { Kelompok Umur } \\
\text { (tahun) }\end{array}$ & $\begin{array}{c}\text { Jumlah } \\
\text { (Orang) }\end{array}$ & Persen (\%) \\
\hline 1 & $42-54$ & 18 & 60,00 \\
2 & $55-70$ & 12 & 40.00 \\
\hline & Jumlah & 30 & 100,00 \\
\hline
\end{tabular}

Pada Tabel 2, nampak bahwa sebagian besar petani responden berada pada kelompok umur produktif sebanyak $60 \%$ dan selebihnya berada pada kelompok umur yang kurang produktif sebanyak $40 \%$.

\section{b. Pendidikan}

Petani yang berpendidikan lebih tinggi cenderung bersifat dinamis dan selektif terhadap perubahan teknologi yang ditawarkan. Pendidikan yang lebih tinggi diharapkan dapat merubah pola pikir petani ke arah yang lebih rasional dan lebih tanggap terhadap informasi teknologi dan akses pasar sehingga dapat meningkatkan produksi dan mutu hasil serta dapat menyelesaikan setiap permasalahan yang dihadapinya. Untuk lebih jelasnya mengenai tingkat pendidikan petani responden disajikan pada Tabel 3.

Tabel 3. Keadaan Tingkat Pendidikan Responden di Desa Balobone Kecamatan Mawasangka Tahun 2018

\begin{tabular}{llcr}
\hline No & Tingkat Pendidikan & Jumlah (Orang) & Persen $(\%)$ \\
\hline 1 & Tdk sekolah & 1 & 3,33 \\
2 & Tdk Tamat SD & 1 & 3,33 \\
3 & Tamat SD & 15 & 50,00 \\
4 & Tamat SMP & 10 & 33,34 \\
5. & Tamat SMA & 3 & 10,00 \\
\hline \multicolumn{2}{c}{ Jumlah } & 30 & 100,00 \\
\hline
\end{tabular}

Pada Tabel 3 tampak bahwa dari 30 petani responden terdapat 1 petani responden atau 3,33\% yang tidak sekolah, petani yang tidak tamat sekolah dasar sebanyak 1 orang atau $3,33 \%$, petani yang berpendidikan sekolah menengah pertama sebanyak 10 orang atau $33,34 \%$ dan tamat Sekolah menengah atas sebanyak3orang atau 10\%. Hal ini menunjukan bahwa petani responden yang adadi Desa Balobone sebagian besar tingkat pendidikannya adalah ditingkat SD .dengan kondisi yang demikian maka diharapkan agar petani mengikuti pelatihan ataupun penyuluhan sehingga pola pikir petani dapat berkembang dan memiliki wawasan yang luas.yang pada akhirnya petani dapat menyelesaikan persoalan-persoalan yang dihadapi dalam pengembangan usaha kopra untuk masa-masa yang datang, dapat mengembangkan usahanya dengan efektif dan efisien sehingga diperoleh hasil maksimal sesuaiyang diharapkan oleh setiap petani.

\section{c. Pengalaman Berusahatani}

Pengalaman berusahatani bagi seorang petani responden merupakan proses pendidikan yang diperoleh dari luar sekolah. Pendidikan yang demikian diperleh dari berbagai peristiwa yang dialami, didengar dan dilihat. Pengalaman berusahatani akan selalu membawa perubahan bagi petani dalam mengelola usahatninya. Seorang petani dengan 
pengalaman yang banyak diharapkan dapat menentukan alternatif yang lebih baik sehubungan dengan usahataninya. Pengalaman yang tinggi dapat memberikan suatu pelajaran yang bermanfaat sebab petani dapat belajar dari kesalahan yang pernah terjadi pada dirinya sehingga dapat dijadikan pedoman dalam merubah kebiasaan- kebiasaan yang buruk kearah yang lebih baik dimasa yang akan datang. Pengalaman berusahatani dapat dikatakan cukup berpengalaman apabila menggeluti bidang pekerjaanya selama 5-10 tahun. Sedangkan 10 tahun keatas dikategorikan berpengalaman. (Soeharjo dan Dahlan Patong,1984). Gambaran mengenai petani responden berdasarkan pengalaman berusahatani dapat dilihat pada Tabel 4 sebagai berikut:

Tabel 4. Pengalaman Responden di Desa Balobone Kecamatan Mawasangka Tahun 2018

\begin{tabular}{cccc}
\hline No & $\begin{array}{c}\text { Pengalaman. } \\
\text { (Tahun) }\end{array}$ & Jmh (Orang) & Persen (\%) \\
\hline 1 & $5-10$ & 12 & 40,00 \\
2 & $11-17$ & 18 & 60,00 \\
\hline & Jumlah & 30 & 100,00 \\
\hline
\end{tabular}

Berdasarkan Tabel 4, nampak bahwa petani responden yang memiliki pengalaman 510 tahun sebanyak 10 orang atau $40 \%$, dan petani yang telah berpengalam berkisar $11-$ 17 tahun sebanyak 18 orang atau $60 \%$. Keadaan ini menunjukkan bahwa sebagian besar petani responden yang ada di Desa Balobone dapat dikatakan berpengalaman. Sebagaimana Soeharjo dan Dahlan Patong (1984) bahwa seseorang dikatakan berpengalaman dalam berusahatani apabila telah menggeluti usahataninya lebih dari 10 tahun keatas. Dengan kondisi yang berpengalaman maka petani tentunya sudah mempunyai banyak pengetahuan dalam pengembangan usaha kopra yang dikelolanya,kegagalan yang pernah dialami akan dijadikanpelajaran sebagai perbaikan kedepan sehingga akan berdampak pada pencapaian produksi yang maksimal.

\section{d. Jumlah Tanggungan Keluarga}

Jumlah tanggungan keluarga adalah jumlah semua orang yang merupakan bagian dari unit konsumsi rumah tangga tinggal dalam satu keluarga tani yang secara langsung merupakan tanggungan keluarga tani ataupun tidak tinggal dalam satu keluarga tetapi masih ditanggung oleh petani.

Banyaknya tanggungan keluarga petani akan mempengaruhi aktifitas petani dalam menggerakan usahatninya sebab dengan banyaknya tanggungan keluarga akan memberikan kelancaran kegiatan petani pada golongan usia produktif. Disampnig itu makin besar jumlah tanggungan keluarga maka makin besar pula jumlah kebutuhan yang harus dipenuhi oleh kepala keluarga, sehingga petani dituntut agar lebih giat bekerja untuk memenuhi kebutuhan hidup keluarganya.

Menurut Tohir (1984) bahwa apabila terdapat 3 orang jumlah anggota keluarga dikatakan keluarga kecil, 4- 6 orang dikatakan sedang dan diatas 6 orang dikatakan keluarga besar. Jumlah tanggung keluarga petani responden dalam penelitian ini disajikan pada Tabel 10 sebagai berikut:

Tabel 5. Jumlah Tanggungan Keluarga Petani Responden Di Desa Balobone Kecamatan Mawasangka Tahun 2018 


\section{Media Agribisnis}

Vol. 3, Issue 2, November 2019

P-ISSN: 2527-8479 E-ISSN: 2686-2174

\begin{tabular}{|c|c|c|r|}
\hline No & Tanggungan Keluarga (Jiwa) & Jumlah (Jiwa) & Persen (\%) \\
\hline 1 & $1-3$ & & 40,00 \\
2 & $4-6$ & 12 & 60,00 \\
\hline & Jumlah & 30 & 100,00 \\
\hline
\end{tabular}

Pada Tabel 5, nampak bahwa jumlah tanggungan keluarga petani responden di daerah penelitian berkisar 1- 6 jiwa. Petani responden dengan jumlah tanggungan keluarga $1-3$ jiwa sebanyak 12 orang atau $40 \%$ sedangkan petani dengan jumlah tanggungan keluarga $4-6$ orang sebanyak 18 orang atau $60 \%$. Keadaan ini menunjukan bahwa jumlah tanggungan keluarga di Desa Balobone sebagian besar dikategorikan keluarga sedang. Ini berarti bahwa anggota keluarga yang ada tersebut diharapkan dapat membantu kepala keluarga dalam mengelolah usahataninya sebagai sumber tenaga kerja sebab keberhasilan usahatani ditentukan oleh banyaknya anggota keluarga dan kesiapan anggota keluarga tersebut bekerja secara maksimal membantu petani baik dalam memberikan ide atau saran dalam pengambilan keputusan maupun tenaga yang dicurahkan dalam pengembangan pengolahan kopra yang lebih baik.

\section{Deskripsi Usahatani}

\section{a. Luas Lahan Garapan}

Luas lahan garapan menentukan jumlah produksi yang dapat dihasilkan oleh petani dalam usahatani yang dikelolanya. Petani yang memiliki lahan yang luas dapat menanam lebih banyak tanaman sehingga hasil produksi yang diperoleh akan lebih banyak

Berdasarkan hasil penelitian menunjukkan luas lahan garapan petani responden berkisar antara 0,5 - 2,5 Ha, dengan luas lahan rata - rata 1,4 Ha. Untuk lebih jelasnya dapat dilihat pada Tabel 6

Tabel 6. Luas Lahan Garapan Usahatani Kelapa di Desa Balobone Kecamatan Mawasangka Tahun 2018

\begin{tabular}{rccr}
\hline No & $\begin{array}{c}\text { Luas Lahan garapan } \\
(\mathrm{Ha})\end{array}$ & $\begin{array}{c}\text { Jumlah } \\
(\text { Orang) }\end{array}$ & Persen(\%) \\
\hline 1 & $0,5-1,1$ & 13 & 43,33 \\
2 & $1,2-1,8$ & 8 & 26,66 \\
3 & $1,9-2,5$ & 9 & 30,01 \\
\hline & Jumlah & 30 & 100,00 \\
\hline
\end{tabular}

Pada Tabel 6 nampak bahwa petani responden yang memilki luas lahan berada pada kisaran $0,5-1,1$ hektar berjumlah 13 orang atau 43,33\%, petani responden yang memiliki luas lahan berada pada kisaran $1,2-1,8$ hektar berjumlah 8 orang atau $26,66 \%$. Sedangkan petani dengan luas lahan 1,9 - 2.5 hektar berjumlah 9 orang atau 30,01\%. Keadaaan ini menggambarkan bahwa sebagian besar petani responden memiliki lahan yang kecil sesuai dengan luas lahan yang di Desa Pebaoa. Dengan luas lahan yang dimiliki diharapkan dapat dimanfaatkan dengan efisien sehingga dapat memberikan hasil produksi yang maksimal.

\section{c. Produksi}


Produksi yang dimaksud adalah produksi kopra yang dihasilkan petani Jumlah produksi kopra yang dihasilkan dalam satu tahun yang diukur dalam satuan $\mathrm{Kg} /$ tahun. Berdasarkan hasil penelitian yang dilakukan menunjukan petani yang ada di desa Balobone mampu menghasilkan 4 kali produksi kopra dalam setahun. Pencapaian produksi yang dihasilkan rata-rata $1.275 \mathrm{Kg} /$ Tahun dengan luas lahan rata-rata $1,4 \mathrm{Ha}$.Untuk lebih jelasnya dapat dilihat pada Tabel 7.

Tabel 7. Produksi Kopra Petani Responden di Desa Balobone Kecamatan Mawasangka Tahun 2018

\begin{tabular}{cccc}
\hline No & Produksi (Kg) & Jumlah (Orang) & $\begin{array}{c}\text { Persen } \\
(\%)\end{array}$ \\
\hline 1 & $500-1.500$ & 24 & 80,00 \\
2 & $1.501-2.501$ & 4 & 30,00 \\
3 & $2.502-3.500$ & 2 & 6,67 \\
\hline & Jumlah & 30 & 100,00 \\
\hline
\end{tabular}

Berdasarkan Tabel 7 menunjukkan bahwa petani yang mampu menghasilkan jumlah produksi berkisar $500-1.500 \mathrm{Kg}$ sebanyak 24 orang $80 \%$, petani yang menghasilkan produksi kopra berkisar $1501-2.501 \mathrm{Kg}$ sebanyak 4 orang atau $30 \%$, sedangkan petani yang mampu menghasilkan produksi kopra berkisar $2.502-3.500 \mathrm{~kg}$ sebanyak 2 orang atau $6,67 \%$. Keadaan ini menggambarkan sebagian besar petani hanya menghasilkan jumlah produksi dalam jumlah yang kecil. Dengan jumlah produksi kopra yang dihasilkan petani dapat menerima harga yang layak sehingga dapat membayar biaya kegiatan pengolahan kopra serta dapat membiayai kebutuhan hidupnya sekaligus mengembangkan usaha kopra yang telah digelutinya sudah sekian tahun.

\section{Identtitas Pedagang Responden}

Identitas merupakan salah satu faktor yang mempengaruhi pedagang dalam melakukan aktivtas bisnis kopra. Identitas yang dimaksud adalah umur, tingkat pendidikan, jumlah tanggungan keluarga dan pengalaman berdagang kopra.

Tabel 8. Identitas Pedagang Responden di Desa Balobone Kecamatan Mawasangka Tahun 2018

\begin{tabular}{cccccc}
\hline No & Uraian & Umur & Pend. & Tanggungan & Pengalaman \\
\hline 1 & PPD & 58 & SMP & 3 & 10 \\
2 & PAP & 62 & SMP & 5 & 8 \\
3 & PB & 50 & SMA & 4 & 6 \\
\hline
\end{tabular}

Hasil penelitian menunjukkan umur pedagang pengumpul desa (PPD) 58 tahun dan umur pedagang antar pulau (PAP) 62 tahun sedangkan umur pedagang besar (PB) 50 tahun., keadaan ini menggambarkan kedua pedagang di Desa Balobone berada dalam kelompok usia kurang produktif namun masih memiliki semangat yang sama sebab masih memiliki kemampuan untuk melakukan aktivitas pemasaran.

Tingkat pendidikan yang dicapai pedagang pengumpul desa dan pedagang antar pulau adalah sekolah menengah pertama sedangkan pedagang besar berpendidikan tamat sekolah 
menengah atas. Keadaan ini menggambarkan secara keseluruhan para pedagang yang terlibat dalam proses pemasaran kopra telah mengikuti pendidikan formal sehingga memungkinkan bagi para pedagang untuk mengikuti perkembangan harga dan dapat melakukan proses pemasaran yang dapat menguntungkan tidak hanya bagi para pedagang akan tetapi juga bagi para petani.

Jumlah tanggungan keluarga yang dimiliki oleh pedagang pengumpul desa sebanyak 3 orang, pedagang antar pulau 5 orang dan pedagang besar sebanyak 4 orang. Dengan jumlah tanggungan keluarga yang dimiliki diharapkan dapat membantu pedagang sebagai kepala keluarga dalam melakukan kegiatan pemasaran sehingga dapat mengurangi biaya yang dikeluarkan.

Pengalaman berdagang secara umum dapat dikatakan telah berpengalaman sebab berdasarkan data Tabel 7 menujukkan pengalam berdagang di atas 5 tahun. Penjelasan tersebut sesuai dengan pendapat Soeharjo dan Dahlan Patong (1989) yang menjelaskan bahwa seseorang yang telah melakukan kegiatan usahanya diatas lima tahun dikatakan memiliki pengalaman. Dengan pengalaman yang dimilikinya diharapkan dapat melakukan aktiivtas berdagang yang dapat menguntungkan terutama dalam penentuan jumlah kopra yang harus dibeli, waktu yang tepat untuk melakukan kegiatan pembelian dan penjualan dan pihak pihak tujuan pembelian kopra sehingga dari aktivtas bisnis yang dilakukan dapat memberikan kontribusi positif bagi kehidupan pedagang dan perkembangan usaha kopra yang dilakukannya

\section{Saluran Pemasaran}

Saluran pemasaran proses yang dilewati oleh suatu komoditas untuk sampai pihak konsumen. Saluran pemasaran yang dilewati oleh suatu komoditas dapat bersifat pendek dan sederhana maupun panjang. Dalam proses pemasaran tersebut terlibat lembaga pemasaran. Berdasarkan hasil penelitian yang dilakukan menunjukkan bahwa saluran pemasaran kopra di BaloboneKecamatan Mawasangka terdapat 2 pola saluran pemasaran yang digunakan oleh petani yaitu

1. Saluran Pemasaran: Petani $\rightarrow$ Ped.Pengumpul Desa $\rightarrow$ Pedagang Besar (Eksportir Baubau)

\section{Saluran Pemasaran Petani \\ $\rightarrow$ Pedagang Antar Pulau \\ $\rightarrow$ Pedagang} Besar (Surabaya)

Saluran pemasaran kopra yang terbentuk di Desa Balobone melibatkan pedagang pengumpul desa 1 orang dan jumlah pedagang antar pulau 1 orang yang yang berdomosili di Desa Balobone, pedagang besar Baubau dan pedagang besar di Surabaya. Proses pemasaran kopra dapat dijelaskan bahwa pada saluran pemasaran pola 1, petani menjual kopra yang dihasilkanya kepada pedagang pengumpul desa Balobone. Dalam kondisi ini petani telah memiliki langganan masing - masing. Selanjutnya pedagang pengumpul desa melakukan fungsi fisik yaitu menjual kembali kopra tersebut ke pedagang besar yang ada di Baubau dan penjualan terakhir sampai ke pedagang Surabaya. Akan tetapi dalam penelitian ini yang menjadi konsumen akhir adalah pedagang besar Kota Baubau.

Proses Saluran pemasaran kopra pola 2 dapat dijelaskan bahwa petani menjual kopra yang dihasilkan kepada pedagang besar yang ada di Desa Balobone, selanjutnya pedagang besar tersebut menjual kembali produk kopra tersebut kepedagang besar Surabaya. Dalam kondisi ini dapat dijelaskan bahwa pedagang besar tersebut dalam melakukan penjualan tidak melalui pedagang besar (eksportir) baubau akan tetapi langsung melakukan penjualan ke pedagang besar Surabaya yang penjualanya melalui kapal. Proses saluran pemasaran pola I 
dan saluran pemasaran pola 2 berakhir di pedagang eksportir namun pedagang eksportir yang berbeda

Hasil penelusuran menunjukkan dari 30 petani responden terdistribusi ke pedagang pengumpul desa sebanyak 18 petani atau $60 \%$ dan 12 petani terdistribusi kepedagang besar yang ada di Desa Balobone. Untuk lebih jelasnya dapat dilihat pada Tabel 9.

Tabel 9. Distribusi Petani Kopra Berdasarkan Pola Pemasaran diDesa BaloboneTahun 2018

\begin{tabular}{cccc}
\hline No & Pola Saluran & $\begin{array}{c}\text { Jumlah } \\
\text { (orang) }\end{array}$ & $\begin{array}{c}\text { Persentase } \\
(\%)\end{array}$ \\
\hline 1. & Pola 1 & 18 & 60,00 \\
2. & Pola II & 12 & 60,00 \\
\hline & Jumlah & 30 & 100,00 \\
\hline
\end{tabular}

Sesuai data pada Tabel 9 menunjukan bahwa 18 petani responden tersebut dalam memasarkan kopra yang dihasilkan melalui saluran pemasaran pola 1 dan 12 petani memasarkan kopra yang dihasilkan ke pedagang besar desa Balobone. Lebih lanjut terkait jumlah petani yang memasarkan kopra ke pedagang baik pedagang pengumpul desa maupun pedagang besar sesuai dengan keinginan petani karena masing - masing petani responden telah memiliki ikatan terutama para petani telah diberikan modal oleh para pedagang sehingga secara psikologis petani akan menjual kopra yang dihasilkannya kepada pedagang yang telah memberikan modal atau sejumlah uang baik digunakan untuk kegiatan pengolahan kopra maupun untuk memenuhi kebutuhan hidupnya. Pada prinsipnya dapat dikatakan bahwa ketika petani mengalami kesulitan petani mencari solusi dengan menemui pedagang untuk memperoleh sejumlah uang dengn jaminan akan menjual kopra yang dihasilkan kepada pedagang tersebut.

Penentuan harga kopra yang berlaku di Balobone, sesuai dengan hasil penelitian bahwa harga yang berlaku ditingkat pedagang pengumpul Desamaupun pedagang besar Desa Balobone $\mathrm{Rp} 4.700 / \mathrm{Kg}$ yang dalam hal ini tidak ada perbedaan harga diantara para pedagang. Berikut disajikan data harga jual di tingkat petani ke pedagang pengumpul desa maupun pedagang antar pulau pada Tabel 10.

Tabel 10. Keadaan Petani Responden Berdasarkan Harga Rata-rata Kopra pada Lembaga Pemasaran di BaloboneKecamatan Mawasangka Tahun 2018

\begin{tabular}{llccc}
\hline No & Lembaga Pemasaran & Hrga Jual (Rp/Kg) & Jmh (orang) & Persentase (\%) \\
\hline 1 & Pedagang Peng.Desa & 4.700 & 18 & 60,00 \\
2 & Pedagang Antar Pulau & 4.700 & 12 & 40,00 \\
\hline J u m 1 a h & - & 30 & 100,00 \\
\hline
\end{tabular}

Pada Tabel 10 nampak bahwa rata-rata petani responden cenderung menjual kopra yang dihasilkannya pada Pedagang Pengumpul desa dengan harga Rp. 4.700/kg sebanyak 18 orang atau $60 \%$, sedangkan 12 petani atau $40 \%$ menjual kopra yang dihasilkannya kepada 


\section{Media Agribisnis}

Vol. 3, Issue 2, November 2019

P-ISSN: 2527-8479 E-ISSN: 2686-2174

pedagang antar pulau dengan harga $\mathrm{Rp} 4.700 / \mathrm{Kg}$.berikut disajikan tabel mengenai harga jual ditingkat pedagang.

Tabel 11. Keadaan Harga Jual Kopra Kopra pada Tingkat Pedagang Besar di BaloboneKecamatan Mawasangka Tahun 2018

\begin{tabular}{ccccc}
\hline No & Lembaga Pemasaran & $\begin{array}{c}\text { Harga Jual } \\
(\mathrm{Rp} / \mathrm{Kg})\end{array}$ & $\begin{array}{c}\text { Jmh } \\
(\text { orang })\end{array}$ & $\begin{array}{c}\text { Persentase } \\
(\%)\end{array}$ \\
\hline $\begin{array}{l}\text { 1. } \\
\text { Dedagang Pengumpul }\end{array}$ & 5.300 & 18 & 60,00 \\
2. & & & \\
\hline & J u m l a h & 9.000 & 12 & 40,00 \\
\hline
\end{tabular}

Berdasarkan Tabel 11 terlihat adanya perbedaan harga terjadi pada saat pedagang pengumpul desa menjual kopra tersebut kepada pedagang besar (eksportir) Baubau Rp $5.300 / \mathrm{Kg}$ sedangkan pedagang antar pulau menjual kopra yang dibeli dari pedagang ke pedagang besar Surabaya tanpa perantara pedagang besar Baubau (eksportir) dengan harga jual $\mathrm{Rp} 9.000 / \mathrm{Kg}$. besarnya perbedaan harga jual $\mathrm{Rp} 4.000 / \mathrm{Kg}$ antara pedagang pengumpul desa dengan pedagang antar pulau disebabkan pedagang antar pulau mengeluarkan biaya pemasaran yang lebih besar dibandingkan dengan pedagang pengumpul desa yang hanya mengeluarkan biaya tenaga kerja dan biaya transportasi.

\section{Margin Pemasaran}

Margin pemasaran adalah selisih antara harga jual di tingkat pedagang dengan harga di itngkat petani produsen. Dalam penelitian ini margin pemasaran merupakan selisih antara harga di tingkat pedang besar/pedagang antar pulau dengan harga jual di tingkat petani. Apabila pemasaran suatu komoditi melibatkan beberapa lembaga pemasaran dalam suatu saluran distribusi, maka margin pemasarannya merupakan penjumlahan dari seluruh margin pemasaran tiap lembaga pemasaran yang terlibat dalam saluran pemasaran tersebut.Berikut disajikan tabel margin pemasaran, biaya dan keuntungan yang diperoleh dari tiap lembaga pemasaran yang terlibat dalam pemasaran kopra.

Tabel 12. Analisa Margin Pemasaran, Biaya dan Keuntungan Lembaga Pemasaran Pada Saluran Pemasaran 1 di Desa BaloboneKecamatan Mawasangka Tahun 2018

No. $\quad \mathrm{U}$ r a i a $\quad$ Harga Jual $(\mathrm{Rp} / \mathrm{Kg}) \quad$ Margin Pemasaran $(\mathrm{Rp} / \mathrm{Kg})$




\section{Media Agribisnis}

Vol. 3, Issue 2, November 2019

P-ISSN: 2527-8479 E-ISSN: 2686-2174

1. Petani

4.700

2. Pedagang Pengumpul desa

Harga beli

Biaya-biaya:

- Tenaga Kerja / Buruh 100

- Transportasi 250

600

- Total biaya 350

- Margin 600

- harga Jual 5.300

- Keuntungan 180

3. Pedagang Besar (Eksportir)

Harga beli

Biaya-biaya

- Transportasi 100

- Pengepakan 50

- Upah Buruh 100 3.700

- Biaya pengeringan 50

- Upah buruh ke container 33

- Iuran pelabuhan 60

- Biaya container 300

- Karung 87,5

- Susut 376

- Total biaya $1.156,5$

- Margin

- Harga jual

9.000

- Keuntungan $2.543,5$ 


\section{Media Agribisnis}

Vol. 3, Issue 2, November 2019

P-ISSN: 2527-8479 E-ISSN: 2686-2174 
Sesuai data Tabel 12 nampak bahwa margin pemasaran yang diperoleh pedagang pengumpul desa pada Saluran Pemasaran 1 sebesar Rp. 600/Kg dengan total biaya yang dikeluarkan sebesar Rp. 350/Kg, keuntungan yang diperoleh sebesar Rp. 250/Kg. Sedangkan margin pemasaran pada pedagang besar sebesar (Eksportir) $\mathrm{Rp} 3.700 \mathrm{Kg}$, biaya yang dikeluarkan meliputi biaya transportasi $\mathrm{Rp} 100 / \mathrm{Kg}$, biaya pengepakan $\mathrm{Rp} 50 / \mathrm{kg}$, biaya

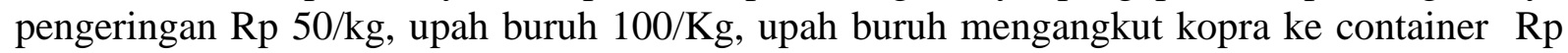
$33 / \mathrm{Kg}$, pembelian karung $\mathrm{Rp} 87,5 / \mathrm{kg}$, iuran pelabuhan $60 / \mathrm{kg}$, biaya container $\mathrm{Rp} 300 / \mathrm{Kg}$, susut Rp 376/kg dengan demikian total biaya yang dikeluarkan sebesar Rp1.156,5 / Kg dengan keuntngan yang diterima sebesar $\mathrm{Rp} 2.543,5 / \mathrm{Kg}$. Besarnya perbedaan margin pemasaran tersebut disebabkan besarnya biaya yang harus dikeluarkan oleh pedagang besar. Kondisi ini tentu akan berdampak pada penetuan harga ditingkat pedagang besar Rp 9.000/Kg. Dengan demikian total margin pemasaran pada saluran pola 1 sebesar $\mathrm{Rp}$ $4.300 / \mathrm{Kg}$.

Proses pemasaran kopra pada saluran pemasaran pola 2 melibatkan pedagang antar pulau yang berdomisili di Desa Balobone, dan pedagang besar Surabaya. Dalam pemasaran tersebut pedagang antar pulau melakukan fungsi pemasaran yang meliputi pengeringan kopra, pengemasan. Untuk melakukan kegiatan tersebut pedagang antara pulau mengeluarkan biaya pengeringan sebesar 50/Kgdan biaya pengemasan 50/Kg. Pedagang antar pulau melakukan pengeringan kembali pada kopra yang telah dibeli dengan tujuan untuk mendapatkan kopra yang berkualitas sehingga memperoleh nilai jual yang tinggi. Dari hasil pengeringan tersebut terjadi penurunan jumlah kopra yang dihasilkan sebesar $8 \%$ sehingga pedagang besar Baubau menerima biaya susut Rp 300/kg. Dalam kondisi ini pedagang antar pulau langsung menjual ke pedagang Surabaya sehingga memberikan perlakuan dan perhatian sesuai dengan standar.

Tabel 13. Analisa Margin Pemasaran, Biaya dan Keuntungan Lembaga Pemasaran Pada Saluran Pemasaran 2 di Desa Balobone Kecamatan Mawasangka

\begin{tabular}{|c|c|c|c|}
\hline \multirow[t]{2}{*}{ No. } & \multirow[b]{2}{*}{$\mathrm{U} r$ a i a $n$} & \multirow[t]{2}{*}{ Harga Jual (Rp/Kg) } & \multirow[b]{2}{*}{ Margin Pemasaran $(\mathrm{Rp} / \mathrm{Kg})$} \\
\hline & & & \\
\hline 1 & Petani & 4.700 & \\
\hline \multirow[t]{10}{*}{2} & Pedagang antar pulau & - & \\
\hline & Harga beli & 4.700 & \\
\hline & Biaya-biaya & & \\
\hline & -Pengepakan & 50 & \\
\hline & - Pengeringan & 50 & \\
\hline & -Transportasi & 250 & \\
\hline & - Tenaga kerja/pikul & 100 & 4.300 \\
\hline & - Upah buruh ke container & 33 & \\
\hline & - iuran pelabuhan & 60 & \\
\hline & - biaya container & 300 & \\
\hline
\end{tabular}


- Biaya susut

- Karung

- Total biaya

- Margin

-Keuntungan

- Harga jual
424

87,5

$1.354,5$

4.300

$2.945,5$

9.000

Berdasarkan Tabel 13 nampak bahwa harga jual koprapetani ke Pedagang antar pulau pada saluran pemasaran pola 2 sebesar $\mathrm{Rp} 4.700 / \mathrm{Kg}$. pedagang antar pulau pada saat melakukan fungsi penjualan ke pedagang besar yang ada di Surabaya mengeluarkan biaya pengepakan $\mathrm{Rp} 50 / \mathrm{Kg}$, pengeringan $\mathrm{Rp} 50 / \mathrm{Kg}$, biaya pengangkutan kopra sampai ke Kota Baubau sebesar Rp 250/Kg, upah buruh Rp 100/Kg, upah buruh ke container Rp 33/Kg dan biaya container sebesar $\mathrm{Rp} 300 / \mathrm{Kg}$., biaya pembelian karung $87,5 / \mathrm{Kg}$, biaya susut 424/Kgdengan demikian total biaya yang dikeluarkan oleh pedagang antar pulau sebesar Rp $1.354,5 / \mathrm{Kg}$, dengan keuntungan sebesar $2.945,5 / \mathrm{Kg}$, sedangkan margin pemasaran yang diterima sebesar Rp sebesar Rp. 4.300/Kg.

Berdasarkan hasil analisis Margin Pemasaran dari ketiga saluran pemasaran di atas nampak adanya perbedaan harga jual kopra dan jumlah Margin Pemasaran dari tiap saluran pemasaran. Perbedaan ini juga akan mempengaruhi persentase bagian harga yang diterima petani dari tiap saluran pemasaran yang digunakan petani.

Hasil analisis margin pemasaran, biaya dan keuntungan pada saluran pemasaran pola 1 dan pola 2 masing - masing memberikan keuntungan yang berbeda. Demikian halnya dengan biaya yang dikeluarkan oleh masing - masing pedagang. Walaupun pada akhirnya kedua saluran pemasaran memberikan margin total yang sama yaitu sebesar Rp 4.300/Kg. karena harga jual di tingkat petani sebesar $\mathrm{Rp} 4.700 / \mathrm{Kg}$ sedangkan harga jual di tingkat pedagang besar dan eksportir sebesar Rp 9.000/kg. yang membedakan dari kedua saluran pemasaran adalah adanya adanya rantai pemasarannya yang panjang, sebelum kopra sampai ke pedagang besar maka komoditas koprta tersebut melalui pedagang pengumpul desa, pedagang besar (eksportir) Baubau sedangkan pada saluran pemasaran pola 2 dari pedagang antara pulau langsung di jual ke pedagang besar Surabaya. Sehingga tingkat keuntungan yang diterima oleh pedagang pengumpul pada saluran pemasaran pola 1 hanya Rp 250/kg. Nilai tersebut lebih kecil jika dibandingkan dengan keuntungan yang diterima oleh pedagang antar pulau pada saluran pemasaran pola $1 \mathrm{Rp} 2.543,5 / \mathrm{Kg}$ dan pedagang besar Kota Baubau Rp $2.945,5 / \mathrm{kg}$ pada saluran pemasaran pola 2

\section{Efisiensi Pemasaran}

Besarnya persentase bagian harga yang diterima oleh petani dalam suatu sistem pemasaran dapat digunakan sebagai acuan dalam mengukur efisien atau tidaknya suatu sistem pemasaran yang digunakan petani. Jika persentase bagian harga yang diterima petani lebih besar dari $50 \%$ maka dapat dikatakan bahwa sistem pemasaran tersebut efisien, sebaliknya maka sistem pemasaran tersebut tidak efisien. Sebagaimana Mubyarto (1982) bahwa sistem tataniaga dapat dianggap efisien apabila memenuhi dua (2) syarat, yaitu: (1) mampu menyampaikan hasil-hasil dari petani (produsen) kepada konsumen dengan biaya semurahmurahnya; dan (2) mampu mengadakan pembagian yang adil dari keseluruhan harga yang 
dibayar konsumen terakhir kepada semua pihak yang terlibat dalam kegiatan produksi dan tataniaga produk tersebut. Untuk mengetahui besarnya persentase bagian harga yang diterima petani, berikut disajikan Tabel 14 persentase bagian harga yang diterima petani responden di Balobone.

Tabel 14. Persentase Bagian Harga yang Diterima Petani Responden dari Harga yang Diterima oleh Lembaga Pemasaran pada Setiap Saluran Pemasaran di Balobone Kecamatan Mawasangka.

\begin{tabular}{ccccc} 
No. & $\begin{array}{c}\text { Saluran } \\
\text { Pemasaran }\end{array}$ & $\begin{array}{c}\text { Margin } \\
(\mathrm{Rp} / \mathrm{Kg})\end{array}$ & $\begin{array}{c}\text { Harga Jual Pedagang } \\
(\mathrm{Rp} / \mathrm{Kg})\end{array}$ & Ep = 1 - M/He x100\% \\
\hline 1. & I & 4.300 & 9.000 & 53 \\
2. & II & 4.300 & 9.000 & 53 \\
\hline
\end{tabular}

J u m l a h

Sesuai data Tabel 14 menunjukkan margin total pada saluran pemasaran pola 1

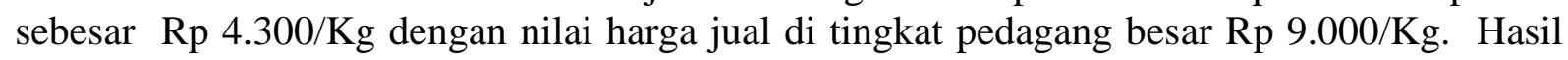
analisis efisiensi pemasaran pola diperoleh nilai $53 \%$, efisiensi pemasaran pada saluran pemasaran pola 2 sebesar 53\%. Nilai efisiensi tersebut menujukkan bahwa sistem pemasaran kopra di Desa Balobone efisien. Hal ini sesuai dengan pendapat Nurland (1989) bahwa nilai efisiensi pemasaran yang diperoleh lebih besar dari 50\% (Ep>50\%) maka saluran pemasarannya sudah efisien. Keadaan ini menggambarkan bahwa persentase bagian harga yang diterima oleh petani merupakan salah satu alat ukur untuk mengetahui efisiensi tidaknya saluran pemasaran yang dilalui oleh setiap komoditi yang dipasarkan

\section{KESIMPULAN DAN SARAN}

\section{Kesimpulan}

Berdasarkan hasil analisis dan pembahasan, maka dapat dikemukakan beberapa kesimpulan sebagai berikut:

1. Petani dalam memasarkan kopra yang dihasilkanya melalui 2 pola Saluran pemasaran yaitu:
a. Saluran Pemasaran Pola I:
Petani -- $\rightarrow$ Ped.Pengumpul Desa $---\rightarrow$ Pedagang Besar I (Eksportir)
b. Saluran Pemasaran Pola II
Petani --- $\rightarrow$ Ped. antar pulau --- $\rightarrow$ Pedagang besar Surabaya

2. Hasil analisis Margin Pemasaran pola 1 yang diterima pedagangmenunjukkan bahwa margin pemasaranyang diterima pedagang pengumpul desa $\mathrm{Rp} 600 / \mathrm{Kg}$, biaya $\mathrm{Rp}$ $350 / \mathrm{Kg}$, Keuntungan Rp 250/Kg, sedangkan margin pemasaran pedagang besar Kota Baubau $\mathrm{Rp} 3.700 / \mathrm{kg}$, dengan biaya $\mathrm{Rp} 1.354,5 . / \mathrm{Kg}$, keuntungan yang diterima $\mathrm{Rp}$ $2.543,5 / \mathrm{Kg}$. Margin pemasaran pola 2 yang diterima pedagang antar pulau $\mathrm{Rp} 4.300$, dengan total biaya yang dikeluarkan $\mathrm{Rp} 1.354,5 / \mathrm{Kg}$, keuntungan yang diterma Rp $2.945,5 / \mathrm{Kg}$ 
3. Persentase bagian harga yang diterima petani dari masing-masing pola saluran pemasaran I sebesar 53\% dan Pola saluran pemasaran 2 sebesar 53. Dengan demikian sistem pemasaran kopra dari 2 pola saluran pemasaran yang terbentuk di Desa Balobone efisien.

\section{Saran}

Berdasarkan kesimpulan di atas, dapat dikemukakan beberapa saran sebagai berikut:

1. Hendaknya pemerintah dapat memberikan modal kepada petani sebagai modal pengembangan usaha pengolahan kopra sehingga petani sebagai pengolah kopra tidak terikat dengan pedagang pengumpul sebagai akibat pinjaman yang dilakukan oleh pengolah sebelum melakukan penjualan

2. Diharapkan kepada para petani sebaiknya menerapkan cara pengolahan kopra yang sesuai standar sehingga dapat menghasilkan kopra yang berkualitas yang berdampak pada peningkatan nilai jual kopra yang dihasilkan dan peningkatan kesejahteraan petani tercapai

3. Hendaknya bagi para pedagang tidak mempermainkan harga dan memberikan informasi perubahan harga jual kopra kepada petani dan menerapkan prinsip sama - sama menguntungkan.

\section{DAFTAR PUSTAKA}

Angipora, M. 2005. Dasar-dasar Pemasaran. Edisi Kedua. Raja Grafindo Persada. Jakarta.

Budianto, J. dan D. Allorerung. 2003. Kelembagaan Perkelapaan. Prosiding Konferensi Nasional Kelapa V. Tembilahan, 22-24 Oktober 2002. Pusat Penelitian dan Pengembangan Perkebunan, Bogor. hlm. 1-9.

Badan Pusat Statistik. 2017. Sulawesi Tenggara Dalam Angka. BPS. Kendari

Dahl DC dan Hammond JW. 1977. Market and Price Analysis. The Agricultural Industries. Mc. Graw-Hill Book Company, Inc

Mubyarto. 1989. Pengantar Ekonomi Pertanian, LP3ES, Jakarta.

Nazir, M. 1999. Metodologi Penelitian. Jakarta: Ghalia Indonesia.

Singarimbun, M. dan Effendi, S. 1989, Metode Penelitian Survei, Lembaga Penelitian Pendidikan dan Penerangan Ekonomi dan Sosial, Jakarta.

Suhardiyono, L. 1993. Saluran Pemasaran, Konsep \& Strategi Analisa Kuantitatif, BPFEUGM, Yogyakarta. 